\title{
Soil Test Crop Response studies on Cowpea (Vigna unguiculata (L). Walp.) in Mollisol of Uttarakhand, India
}

\author{
Varun Tripathi*, Sobran Singh ${ }^{1}$ and Bal Mukund Pandey ${ }^{2}$
}

${ }^{1}$ Department of Soil Science, College of Agriculture, G.B. Pant University of Agriculture and Technology, Pantnagar, Uttarakhand, 263145, India

${ }^{2}$ Department of Agriculture, T. D. P.G. College Jaunpur, U.P. India

*Corresponding author

\section{Keywords}

Mollisol, Fertilizer recommendation, Cowpea, Yield target and nutrient requirement

Article Info

Accepted: 15 April 2019 Available Online: 10 May 2019

\section{A B S T R A C T}

A field experiment was conducted during spring 2009-2010 in a Aquic hapludoll at the Norman E. Borlaug Crop Research Centre of the G.B. Pant University of Agriculture and Technology, Pantnagar ( $29^{\circ} \mathrm{N}$ latitude and $79^{\circ} 29^{\prime} \mathrm{E}$ longitude), as per technical programme of All India Coordinated Research Project on the soil test crop response correlation. The experiment was conducted in "two-phases". In the first phase soil fertility gradient was developed by dividing the experimental field into "three strips" and applying graded doses of fertilizers in them (Strip I no fertilizer), Strip II $(100,100$ and $100 \mathrm{~kg} / \mathrm{ha}$ $\mathrm{N}, \mathrm{P}_{2} \mathrm{O}_{5}$ and $\mathrm{K}_{2} \mathrm{O} / \mathrm{ha}$ ) respectively, and strip III (200, 200 and $200 \mathrm{~kg} \mathrm{~N}, \mathrm{P}_{2} \mathrm{O}_{5}$ and $\mathrm{K}_{2} \mathrm{O}$ ) respectively and growing of exhaust crop Oat (Var. Kent). In the second phase, i.e. next season test crop Cowpea (var. Pant lobia-1) was grown by dividing each strip into twentyfour plots having twenty-three fertilizer treatments and one control plot. Response to "select" combinations of "three-levels" of FYM (0, 5 and $10 \mathrm{t} / \mathrm{ha})$, "four-levels" of nitrogen $(0,15,30$ and $45 \mathrm{~kg} / \mathrm{ha})$, four levels of phosphorus $(0,30,60$ and $90 \mathrm{~kg} / \mathrm{ha})$ and four levels of potassium $(0,30,60$ and $90 \mathrm{~kg} / \mathrm{ha})$ at different fertility levels of cowpea was studied. The values of the organic carbon, Alkaline $\mathrm{KMnO}_{4}$ extractable $\mathrm{N}$, Olsen's $\mathrm{P}$ and neutral normal Ammonium Acetate extractable $\mathrm{K}$ in the experimental field ranged between $0.72-1.16$ per cent, $112.30-200.60 \mathrm{~kg} / \mathrm{ha}, 13.00-24.24 \mathrm{~kg} / \mathrm{ha}$ and $101.90-245.30 \mathrm{~kg} / \mathrm{ha}$, respectively. In the present investigation the total straw yield ranged from 13.07-24.94 $\mathrm{q} / \mathrm{ha}$ and total grain yield ranged from 9.00-18.20 $\mathrm{q} / \mathrm{ha}$. The nutrient requirement for production of one quintal of cowpea grain was found to be $5.71 \mathrm{~kg}$ of nitrogen, $0.90 \mathrm{~kg}$ of phosphorus and $3.72 \mathrm{~kg}$ of potassium. Per cent contribution of nitrogen, phosphorus and potassium was $62.00,59.00$ and 32.00 from soil, whereas from other sources as FYM was 7.00, 29.00, 10.00; chemical fertilizer 30.00, 14.00 and 30.00 and conjoint use of chemical fertilizer with FYM 30.00, 17.00 and 27.00 in terms of NPK respectively. With the help of these data fertilizer recommendation at different yield targets and soil test value can be calculated. Coefficient of quadratic multiple regression $\left(\mathrm{R}^{2}\right)$ was found highly significant $\left(0.898^{*} *\right)$ between grain yield, soil test values, added fertilizers and FYM. Organic carbon, alkaline $\mathrm{KMnO}_{4}-\mathrm{N}$, Olsen's-P and AB DTPA and Ammonium acetate $\mathrm{K}$ and AB DTPA K methods of available $\mathrm{N}, \mathrm{P}$ and $\mathrm{K}$ respectively were at par for the cowpea grown in Mollisol of Uttarakhand. 


\section{Introduction}

Cowpea (Vigna ungiculata (L.) Walp), an annual legume, also commonly referred to as southern pea, black eyed pea, crowder pea, lobia, niebe coupe or frijole. It is one of the ancient crops to man. The history of cowpea dates to ancient West African cereal farming, 5 to 6 thousand years ago, where it was closely associated with the cultivation of sorghum and pearl millet. It is also grown in Latin America, and southern United States. The black- eyed cowpea type is grown up primarily in California and marketed as California black-eyed pea. Worldwide production of cowpea has increased dramatically in the last 25 years. It is a warmseason crop well adapted to many areas of the humid tropics and temperate zones. It tolerates heat and dry conditions but is intolerant of frost. This crop has a considerable promise as an alternative pulse crop in dry land farming. Cowpea performs best on well-drained sandy loam or sandy soils where soil $\mathrm{pH}$ is in the range of 5.5 to 6.5. Being a leguminous crop, it requires soil application of NPK as a starter dose for better initial establishment. In an estimate, 3.3 million tons of cowpea dry grains were produced worldwide during the year 2000 . The world average yield was $337 \mathrm{~kg} / \mathrm{ha}$ (Bressani et al., 1985); IITA, (2000). Within India; cowpea is grown in an area of 3.9 million hectares with a production of 2.21 million tones and productivity of $567 \mathrm{~kg} / \mathrm{ha}$. Pulses are the important sources of proteins, vitamins and minerals for the predominantly vegetarian population and are popularly known as "poor man's meat" and "rich man's vegetable" (Singh et al., 1992). Importance of fertilizer to increase food grain production is well recognized. Agricultural production is intensifying by the sharp increase in fertilizer consumption, but productivity gains of added nutrients are declining. Nutrient supply from chemical fertilizers is the key to increase the agricultural production. Enhanced land productivity results from the synergistic effects of chemical fertilizers, organic manures, biofertilizers and other locally available nutrient sources, which improve soil organic carbon, and nutrient status consequently chemical, physical and biological properties of soil. Since plants derive nutrients from both soil and fertilizers, it is necessary to minimize the wastage of fertilizer status in the soil to ensure their economic and judicial use. The need of to use renewable forms of energy have revived the use of organic fertilizers worldwide. Nutrients contained in organic manures are released more slowly and are stored for a longer time in the soil, thereby ensuring a long residual effect (Sharma et al., 1991). Improvement of environmental conditions and public health as well as the need to reduce the cost of fertilizing crops are also important reasons for advocating increased use of organic materials (Seifritz, 1982). Application of organic manures also improves the soil microbial properties Belay et al., (2001). The benefits derivable from the uses of organic materials have however not been fully utilized in the humid tropics due to huge quantities required to satisfy the nutritional needs of crops as well as transportation and handling costs which constitute major constraints. They are rarely available to the small-scale farmers in the required large quantities (Nyathi et al., 1995).

During the post green revolution period, the production of pulses recorded a negative growth rate. This disturbing trend in the production of pulses had adversely affected the per capita availability of pulses. Soil testing is one of the important tools to accesses the fertility status of soil and provide the basis of nutrient requirement for a crops/cropping sequence. This helps to economize the cost of fertilizer use and will increase the fertilizer use efficiency. Soil 
testing also aids in monitoring of soil health and environment over time. In the current and future scenario, soil testing must be renamed as soil quality assessment and it must assume a holistic role not limited to guide fertilizer recommendation for a crop based on soil test Goswami (2006). Hence the soil testing has become the foundation for fertilizing our soils in balanced proportion and to understand nutrient losses from the soil. The soil test values should be correlated and calibrated for recommending the fertilizer requirement of a crop on a specific soil climate zone. In the absence of such information, no precise fertilizer recommendations would be possible. Keeping these factors in view, an All India coordinated research Project on Soil Test Crop Response Correlations was started by the Indian Council of Agricultural Research in the 1967-1968. Various aspects of the problem and approaches for solution were calculated and debated at the national level. Finally detailed technical programme tried up to guide laboratory and field experimentation. In the field experimentation under this programme, the yield variations due to management practices and the soil factors other than the nutrient under study were avoided by creating the desired fertility variations artificially on the same field at few selected sites representing various soil and agro-climatic zones of the country. The concept of formulating optimum fertilizer recommendation for targeted yield was first given by Troug (1960) which further modified by Ramamoorthy et al., (1967).

The relationship between yield of economic part and uptake of a nutrient will usually be linear. This implies that for obtaining a given yield, a definite quantity of the nutrient must be in use by the plant. Once this requirement is recognized for a given yield, a definite quantity of the nutrient must be in use by the plant. Once this requirement is recognized for a given yield, the fertilizer need can be estimated by taking account of efficiency or contribution from the nutrient available in soil and from the fertilizer applied. The data obtained from the Soil Test Crop Response field experiment provides a range in soil test values, nutrient uptake and yield levels, which enables us in calculating the three basic parameters i.e. nutrient requirements, percent contribution from the applied nutrient through inorganic or organic sources. Today, we are overwhelmed to hear that Soil Test Crop Response (STCR) based prescription are gaining popularity due to their superiority over blanket general fertilizer recommendations. Field trials conducted in different agro-ecological zones with different cropping systems revealed that the STCR produced higher yields and maintains better nutrient status as compared to blanket fertilizers recommendation. This approach of efficient fertilizer management increases the production potential for yield of pulses.

\section{Materials and Methods}

Field experiment was conducted in $\mathrm{B}_{3}$ block of Norman E. Borlaug Crop Research Centre (C.R.C), of G.B. Pant University of Agriculture and Technology, Pantnagar, Distt. U S. Nagar, Uttarakhand on Soil Test Crop Response Studies as per the technical programme of A.I.C.R.P. During spring 201011. The Crop Research Centre is situated at the foot hills of Shivalik range of Himalayas at $29^{\circ} \mathrm{N}$ latitude, $79^{\circ} 29^{\prime} \mathrm{E}$ longitude and an altitude of $243.84 \mathrm{~m}$ above the mean sea level. Climate of Pantnagar is humid, subtropical with hot and dry summers and cool winters. The monsoon season usually starts from third or fourth week of June and extends up to last week of September. Few spells of downpours are generally received during winter season (November to march). The average annual rainfall of the area is $1433.3 \mathrm{~mm}$ and approx. $80-90$ percent of it is received during rainy season. Soils of this 
region are developed from medium to moderately coarse textured calcareous alluvium brought down from mountains by numerous streams flowing through Bhabhar and Tarai. These are mainly silty and loamy in texture with weak fine to medium fine granular structure, having good moisture storage capacity and these are considered as a highly productive soil.

Composite soil samples were processed and analysed for various physicochemical properties (Table 1).

In the beginning fertility gradient across the width of field was created by adding different doses of $\mathrm{N}, \mathrm{P}$ and $\mathrm{K}$ fertilizers and growing Oat var.-Kent as exhaust crop, during Rabi 2010. This is for successful soil test crop response correlation study and to minimize the interference of other soil and management factors affecting crop yield response.

In the beginning first phase, 2010 land was prepared in the month of September. For preparation of field one disc ploughing followed by two cross harrowing was done. The field was levelled with the help of tractor drawn leveler to give gentle slope for smooth drainage on the same day. Experimental site was divided into three equal strips and applied three levels of nutrients, viz 0,1 and 2 (i.e.) $\mathrm{N}_{0} \mathrm{P}_{0} \mathrm{~K}_{0}, \mathrm{~N}_{1} \mathrm{P}_{1} \mathrm{~K}_{1}$ and $\mathrm{N}_{2} \mathrm{P}_{2} \mathrm{~K}_{2}$ as given in table 2.

Nitrogen, phosphorus and potash were applied as urea, single super phosphate and muriate of potash, respectively. Half dose of nitrogen and full dose of phosphorus and potash were applied by placement method. The remaining half dose of nitrogen was applied 45 DAS. Line sowing was done at 23 $\mathrm{cm}$ row to row distance and plant to plant to plant distance $5 \mathrm{~cm}$. Seeds of variety Kent were sown at the rate of $100 \mathrm{~kg} / \mathrm{ha}$. For raising the crop recommended agronomic practices were adopted. This crop was harvested at $50 \%$ flowering (Table 3 ).

During second phase a test crop, Cowpea var. Pant lobia-1 was sown on the site of fertility gradient experiment. Land was prepared with one disc ploughing followed by four cross harrowing. The field was leveled without disturbing strip boundaries with the help of leveler to furnish gentle slope for better drainage Each strip was divided into 24 plot (23 treated and one control plot) resulting in total seventy two $(24 \times 3)$ plots $(3 \mathrm{~m} \times 3 \mathrm{~m}$ size $)$ plots. These treatments comprised of various selected combinations of nitrogen, phosphorus, potassium and farmyard manure were randomized in each of the three strips.

Nitrogen, phosphorus, potassium and organic manure were applied through urea, single super phosphate muriate of potash and FYM, respectively. Half of nitrogen, total phosphorus, total potash and total dose of FYM were broadcasted as basal and mix well in soil with spade before sowing. While remaining half of nitrogen was applied 30 DAS. An attempt was made to keep the crop free of weeds, insects, pests and diseases following the recommended agronomic practices.

Soil samples were collected plough layer (0$15 \mathrm{~cm}$ depth) from each plot of strips I, II and III before addition of any manure or fertilizer. Plant samples were collected from each plot at the time of harvest (physiological maturity stage) and were dried to constant weight at $70^{\circ} \mathrm{C}$.

After threshing of the harvested produce of each plot the grain and straw yield was recorded and reported as $\mathrm{q} / \mathrm{ha}$. After recording the grain and straw yield, chemical analysis of soil samples and plant samples was done. After that basic data for fertilizer recommendation was calculated with the help 
of crop yield, nutrient uptake and soil test values. After that statistical analysis was done by the method of simple correlation as well as multiple regression equation (Panse and sukhatme, 1962; Snedecor and Cochran, 1967) and as per standard design of AICRP on Soil Test Crop Response Project of ICAR.

\section{Results and Discussion}

\section{Soil analysis}

Experimental soil was loam classified as Aquic Hapludoll having $\mathrm{pH}$ 6.87, Organic carbon $0.76 \%$, Alkaline $\mathrm{KMnO}_{4}-\mathrm{N}$ 165.07, Olsen's-P 17.69 and Ammonium Acetate-K $274.4 \mathrm{~kg} / \mathrm{ha}$. Strip wise range and mean of soil test values obtained by different soil test methods for nitrogen, phosphorus and potassium are given in table 4 .

From these data it was found that the nitrogen extracted as alkaline $\mathrm{KMnO}_{4}-\mathrm{N}$ was found in the order, strip III > strip II> strip I (Table 4). Similar trend was observed by phosphorus extracted by Olsen's method and potassium extracted by neutral normal ammonium acetate potassium in different strips (Table 4). Therefore, it is concluded that the Alkaline $\mathrm{KMnO}_{4}-\mathrm{N}$, Olsen's-P and neutral normal ammonium acetate potassium content of soil increased in the order of strip $\mathrm{I}<$ strip II $<$ strip III of the experimental site. From these data availability indices of $\mathrm{N}, \mathrm{P}$ and $\mathrm{K}$ were determined by regression equations using uptake as dependent and soil test values, fertilizer doses as independent variables.

\section{Availability indices of nitrogen, phosphorus and potassium}

Nitrogen was determined by alkaline $\mathrm{KMnO}_{4}$ and organic carbon as index of available nitrogen equations showing the relationship by these methods are given below:

\section{I) Organic carbon (\%)}

$\mathrm{UN}=209.487-1.349 \quad \mathrm{FN}+0.0232 \quad \mathrm{FN}^{2}-$ $244.615 \mathrm{SN}+108.625 \mathrm{SN}^{2}+0.916 \mathrm{FNSN}$

$\mathrm{R}^{2}=0.579$

\section{II) Alkaline $\mathrm{KMnO}_{4}-\mathrm{N}$}

$\mathrm{UN}=164.229-1.596 \quad \mathrm{FN}+0.00373 \quad \mathrm{FN}^{2}-$
$1.007 \mathrm{SN}+0.00206 \mathrm{SN}^{2}+0.0148 \mathrm{FNSN}$

Evaluation of $\mathrm{P}$ fertility status of soil is necessary to make a sound $\mathrm{P}$ fertilizer recommendation for optimizing crop yield. TO determine the available $\mathrm{P}$ status various methods are employed by different scientist in most of the soil testing laboratories. The rate and quantity of $\mathrm{P}$ that can be solubilized by a extractants depends on the soil and chemical nature of the extractants used. Following multiple regression equation developed for the evaluation of available phosphorus (Table 5 and 6).

\section{I) Olsen's P}

$\mathrm{UP}=4.270-0.332$ FP-0.00681FP ${ }^{2}+1.110 \mathrm{SP}-$ $0.00507 \mathrm{SP}^{2}+0.00411$ FPSP

$\mathrm{R}^{2}=0.607 * *$

\section{II) AB-DTPA}

$\mathrm{UP}=60.410-0.0748 \quad \mathrm{FP}-0.000667 \quad \mathrm{FP}^{2}-3.938$ $\mathrm{SP}^{2}+0.07604 \mathrm{SP}^{2}+0.00996$ FPSP

$\mathrm{R}^{2}=0.596 * *$

\section{III) Mehlich P}

$$
\begin{aligned}
& \mathrm{UP}=-33.464-0.184 \quad \mathrm{FP}+0.00138 \quad \mathrm{FP}^{2}+1.713 \\
& \mathrm{SP}-0.0177 \mathrm{SP}^{2}+0.00603 \mathrm{FPSP} \\
& \mathrm{R}^{2}=0.619 * *
\end{aligned}
$$

\section{IV) Morgan-P}

$\mathrm{UP}=-33.464-0.184 \quad \mathrm{FP}+0.00138 \quad \mathrm{FP}^{2}+1.713$ 
SP-0.0177 $\mathrm{SP}^{2}+0.00603$ FPSP

$\mathrm{R}^{2}=0.673 * *$

Evaluation of $\mathrm{K}$ fertility of soil is necessary for optimizing fertilizer use and making $\mathrm{K}$ fertilizer recommendation of the crop. Numerous methods have been advocated be several workers to measure the available $\mathrm{K}$ status of the soils but none of these has been found to be universally applicable. The $\mathrm{K}$ Availability depends upon their amount in the soil, soil characteristics, temperature and organic matter content. Following multiple regression equation developed for the evaluation of available potassium.

\section{I) Neutral ammonium acetate}

$\mathrm{UK}=1.403-0.560 \quad \mathrm{FK}-0.00276 \quad \mathrm{FK}^{2}+0.590$ SK-0.00185 $\mathrm{SK}^{2}+0.0498$ FKSK

$\mathrm{R}^{2}=0.616^{* *}$

Table.1 Physicochemical properties of the soil of experimental site $(0-15 \mathrm{~cm}$. soil depth)

\begin{tabular}{|c|c|c|c|}
\hline S. No. & Property & Value obtained & Method employed \\
\hline \multirow[t]{5}{*}{1} & Textural analysis & & \multirow{5}{*}{$\begin{array}{l}\text { Bouycos Hydrometer } \\
\text { method (Black, 1965). }\end{array}$} \\
\hline & Sand $(\%)$ & 50.81 & \\
\hline & Silt (\%) & 32.33 & \\
\hline & Clay (\%) & 16.87 & \\
\hline & Textural class & Loam & \\
\hline 2 & $\begin{array}{l}\mathrm{pH} \text { (1:2.5 soil water } \\
\text { suspension) }\end{array}$ & 6.87 & $\begin{array}{c}\text { Glass electrode pH } \\
\text { meter (Jackson, 1958) }\end{array}$ \\
\hline 3 & Organic carbon $(\%)$ & 0.76 & $\begin{array}{l}\text { Walkley and Black } \\
\text { method }\end{array}$ \\
\hline 4 & $\begin{array}{l}\text { Available nitrogen } \\
\text { (kg/ha) }\end{array}$ & 165.07 & $\begin{array}{c}\text { Alkaline } \mathrm{KMnO}_{4} \\
\text { method (Subbiah and } \\
\text { Asija, 1956). }\end{array}$ \\
\hline 5 & $\begin{array}{l}\text { Available phosphorus } \\
\text { (kg/ha) }\end{array}$ & 17.69 & $\begin{array}{l}\text { Olsen's extraction } \\
\text { method (Olsen } \text { et al., } \\
\text { 1954) }\end{array}$ \\
\hline 6 & $\begin{array}{l}\text { Available Potassium } \\
\text { (kg/ha) }\end{array}$ & 274.4 & $\begin{array}{c}\text { Neutral one normal } \\
\text { ammonium acetate } \\
\text { method (Hanway and } \\
\text { Hiedal, 1952). }\end{array}$ \\
\hline
\end{tabular}

Table.2 Treatments in fertility gradient experiment

\begin{tabular}{|c|c|c|c|}
\hline Strip (Symbol) & \multicolumn{3}{|c|}{ Nutrient level $(\mathbf{k g} / \mathbf{h a})$} \\
\hline & $\mathbf{N}$ & $\mathbf{P}_{\mathbf{2}} \mathbf{O}_{\mathbf{5}}$ & $\mathbf{K}_{\mathbf{2}} \mathbf{O}$ \\
\hline I $\left(\mathbf{N}_{\mathbf{0}} \mathbf{P}_{\mathbf{0}} \mathbf{K}_{\mathbf{0}}\right)$ & 0 & 0 & 0 \\
\hline II $\left(\mathbf{N}_{\mathbf{1}} \mathbf{P}_{\mathbf{1}} \mathbf{K}_{\mathbf{1}}\right)$ & 100 & 100 & 100 \\
\hline III $\left(\mathbf{N}_{\mathbf{2}} \mathbf{P}_{\mathbf{2}} \mathbf{K}_{\mathbf{2}}\right)$ & 200 & 200 & 200 \\
\hline
\end{tabular}


Table.3 Levels of nutrients applied in test crop experiment

\begin{tabular}{|c|c|c|c|c|}
\hline Levels & FYM (t/ha) & N (kg/ha) & $\mathrm{P}_{2} \mathrm{O}_{5}(\mathrm{~kg} / \mathrm{ha})$ & $\mathrm{K}_{2} \mathrm{O}(\mathrm{kg} / \mathrm{ha})$ \\
\hline 0 & 0 & 0 & 0 & 0 \\
\hline 1 & 5 & 15 & 30 & 30 \\
\hline 2 & 10 & 30 & 60 & 60 \\
\hline 3 & - & 45 & 90 & 90 \\
\hline
\end{tabular}

Table.4 Range and mean of the soil test values under different strips

\begin{tabular}{|c|c|c|c|c|c|}
\hline S No. & $\begin{array}{c}\text { Soil test } \\
\text { values }\end{array}$ & Strip I & Strip II & Strip III & Whole field \\
\hline $\mathbf{1}$ & Organic & $0.72-1.02$ & $0.74-1.16$ & $0.72-1.15$ & $0.72-1.16$ \\
& carbon (\%) & $(0.90)$ & $(0.99)$ & $(0.94)$ & $(0.94)$ \\
\hline $\mathbf{2}$ & Alkaline & $112.60-$ & $112.30-$ & $112.60-$ & $112.30-$ \\
& KMnO $-\mathbf{N}$ & 178.60 & 191.29 & 200.60 & 200.60 \\
& $\mathbf{( k g / h a )}$ & $(135.13)$ & $(142.84)$ & $(146.83)$ & $(137.57)$ \\
\hline $\mathbf{3}$ & Olsen's-P & $13.00-23.00$ & $14.60-23.50$ & $15.60-24.24$ & $13.00-24.24$ \\
& & $(17.00)$ & $(18.61)$ & $(20.37)$ & $(18.67)$ \\
\hline $\mathbf{4}$ & Ammonium & $101.90-$ & $120.50-$ & $128.30-$ & $101.90-$ \\
& acetate-K & 215.60 & 221.50 & 245.30 & 245.30 \\
& & $(164.28)$ & $(176.84)$ & $(178.48)$ & $(173.28)$ \\
\hline
\end{tabular}

Table.5 Range and average yield of cowpea under different strips

\begin{tabular}{|c|c|c|c|c|c|}
\hline Particulars & \multicolumn{5}{|c|}{ Whole plots } \\
\hline & Strip I & \multicolumn{2}{|l|}{ Strip II } & Strip III & Whole Plots \\
\hline $\begin{array}{c}\text { Grain yield } \\
\text { (q/ha) }\end{array}$ & $\begin{array}{c}9.00-17.80 \\
(14.57)\end{array}$ & \multicolumn{2}{|l|}{$\begin{array}{c}11.00-18.00 \\
(15.13)\end{array}$} & $\begin{array}{c}11.50-18.20 \\
(15.62)\end{array}$ & $\begin{array}{c}9.00-18.20 \\
(15.11)\end{array}$ \\
\hline $\begin{array}{c}\text { Straw yield } \\
\text { (q/ha) }\end{array}$ & $\begin{array}{c}14.10-22.96 \\
(18.72)\end{array}$ & \multicolumn{2}{|l|}{$\begin{array}{c}13.07-24.94 \\
(18.66)\end{array}$} & $\begin{array}{c}14.42-23.82 \\
(19.46)\end{array}$ & $\begin{array}{c}13.07-24.94 \\
(18.95)\end{array}$ \\
\hline & \multicolumn{5}{|c|}{ Control plots } \\
\hline $\begin{array}{l}\text { Grain yield } \\
\text { (q/ha) }\end{array}$ & $\begin{array}{c}9.00-12.00 \\
(10.50)\end{array}$ & $\begin{array}{c}11.00-12.50 \\
(11.67)\end{array}$ & & $\begin{array}{c}11.50-13.50 \\
(12.67)\end{array}$ & $\begin{array}{c}9.00-13.50 \\
(11.61)\end{array}$ \\
\hline \multirow[t]{2}{*}{$\begin{array}{l}\text { Straw yield } \\
\text { (q/ha) }\end{array}$} & $\begin{array}{c}14.10-15.90 \\
(15.00)\end{array}$ & $\begin{array}{c}13.07-15.95 \\
(14.53)\end{array}$ & & $\begin{array}{c}14.42-16.17 \\
(15.25)\end{array}$ & $\begin{array}{c}13.07-16.17 \\
(14.93)\end{array}$ \\
\hline & \multicolumn{5}{|c|}{ Treated plots } \\
\hline $\begin{array}{l}\text { Grain yield } \\
\text { (q/ha) }\end{array}$ & $\begin{array}{c}13.10-17.80 \\
(15.19)\end{array}$ & $\begin{array}{c}13.50-18.00 \\
(15.62)\end{array}$ & $\begin{array}{c}14.10- \\
18.20 \\
(16.04)\end{array}$ & \multicolumn{2}{|c|}{$\begin{array}{c}13.10-18.20 \\
(15.60)\end{array}$} \\
\hline $\begin{array}{l}\text { Straw Yield } \\
\text { (q/ha) }\end{array}$ & $\begin{array}{c}16.17-22.96 \\
(19.25)\end{array}$ & $\begin{array}{c}15.09-24.94 \\
(19.25)\end{array}$ & $\begin{array}{c}16.50- \\
23.82 \\
(20.06)\end{array}$ & \multicolumn{2}{|c|}{$\begin{array}{c}15.09-24.94 \\
(19.52)\end{array}$} \\
\hline
\end{tabular}


Table.6 Basic data for calculating fertilizer dose with and without FYM for targeted yield of Cowpea

\begin{tabular}{|c|c|lcc|ccc|}
\hline S. No & Particulars & \multicolumn{4}{|l|}{ Without FYM } & \multicolumn{4}{l|}{ With FYM } \\
& & N & P & K & N & P & K \\
\hline $\mathbf{1 .}$ & Nutrient requirement (kg/q) & 5.71 & 0.90 & 3.72 & 5.71 & 0.90 & 3.72 \\
\hline $\mathbf{2 .}$ & $\begin{array}{c}\text { Percent contribution from } \\
\text { applied soil (\%) }\end{array}$ & 62.00 & 59.00 & 32.00 & 62.00 & 59.00 & 32.00 \\
\hline $\mathbf{3 .}$ & $\begin{array}{c}\text { Percent contribution from } \\
\text { applied fertilizer (\%) }\end{array}$ & 30.00 & 14.00 & 30.00 & 30.00 & 17.00 & 27.00 \\
\hline $\mathbf{4 .}$ & $\begin{array}{c}\text { Contribution from applied FYM } \\
\text { nutrients (\%) }\end{array}$ & -- & --- & -- & 7.00 & 29.0010 .00 \\
\hline
\end{tabular}

\section{II) AB-DTPA K}

$\mathrm{UK}=57.776+1.738 \quad$ FK $-0.003 \quad \mathrm{FK}^{2}-0.342$ SK+0.00159 SK $^{2}-0.00807$ FKSK

$\mathrm{R}^{2}=0.781^{* *}$

\section{III) Mehlich-K}

UK=89.50+0.983 FK-0.00019 FK ${ }^{2}-0.251$ SK$0.003516 \mathrm{SK}^{2}-0.00185$ FKSK

$\mathrm{R}^{2}=0.613^{* *}$

\section{IV) Morgan-K}

$\mathrm{UK}=51.381+1.415 \quad$ FK-0.00316 $\quad \mathrm{FK}^{2}-0.351$

SK-0.00264 SK ${ }^{2}-0.00954$ FKSK.

$\mathrm{R}^{2}=0.703 * *$

In the above methods highest $\mathrm{R}^{2}$ was obtained with Alkaline $\mathrm{KMnO}_{4} \mathrm{~N}$, Morgan's $\mathrm{P}$ and AB-DTPA K.

Average grain and straw yields followed the following trend among the strips:

Strip III > Strip II > Strip I

Strip wise average grain yield of cowpea at varying levels of $F Y M\left(F_{0}=0, F_{1}=5\right.$ and $F_{2}=10$ $\mathrm{t} / \mathrm{ha}$ ) of NOPOK0 plots showed the following trend:

Strip III > Strip II> Strip I
Grain yield of cowpea under same strip with varying levels of FYM of control plots showed the following trend:

Strip I: $\mathrm{F}_{2}>\mathrm{F}_{1}>\mathrm{F}_{0}$

Strip II: $\mathrm{F}_{0}>\mathrm{F}_{2}>\mathrm{F}_{1}$

Strip III: $F_{0}>F_{2}>F_{1}$

Fertilizer adjustment equations

Without FYM

$\mathrm{FN}=19.03 \mathrm{~T}-2.06 \mathrm{SN}$

$\mathrm{FP}=6.42 \mathrm{~T}-4.21 \mathrm{SP}$

$\mathrm{FK}=12.40 \mathrm{~T}-1.06 \mathrm{SK}$

\section{With FYM}

$\mathrm{FN}=19.03$ T-2.06 SN-0.21 FYM-N

$\mathrm{FP}=6.42 \mathrm{~T} \_4.21$ SP-1.64 FYM-P

$\mathrm{FK}=12.4 \mathrm{~T}-1.06 \mathrm{SK}-0.370 \mathrm{FYM}-\mathrm{K}$

\section{References}

Bressani, Ricardo., 1984. Nutritive value. In: Singh, S.R. and Rachies, K.O., Eds., Cowpea Research Production and Utilization, John Wiley and Sons, New York. pp 50-51.

Belay, A., A.S. Classens, F.C. Wehner and J.M. De Beer, 2001. Influence of residual manure on selected nutrient 
elements and microbial composition of soil under long-term crop rotation. South Africa. J. Plant and Soil, 18:1-6.

Black, C.A. 1965. Methods of soil chemical analysis: Agronomy series. J. Ann. Soc. Agron Inc. Madison. Wisconsin. USA. 9(2) pp:44-49.

Goswami, P.K.; Bandhopadhyay, K.K.; Misra, R.K. and Subba Rao, A. 2006. Balanced fertilization for maintaining soil health and sustainable agriculture. Ferti News. 49(4): 13-24\&35.

Hanway,J.J and Hiedal, H. 1952. Soil analysis method used in Iowa State Soil Testing Laboratory. Iowa Agric. (c.f. methods of soil analysis, part 2 Ed. C.A. Black., Medison Wisconsin. American Soci of Agron. 57: 1025-1027.

IITA (International Institute of Tropical Agriculture) 2000. Annual Report., Ibadan, Nigeria. IITA. pp .66-67.

Jackson, M.L.1967. Soil chemical analysis. Prentice Hall of India (P) Ltd., New Delhi. Pp. 183-192.

Nyathi, P. and Campbell B.M., 1995. The Effect of Tree Leaf Litter, Manure, Inorganic Fertilizer and their contribution on above-ground production and grain yield of Maize. African Crop Science Journal:3(4):451456.

Olsen, S.R.; Cole, C.V.; Watanabe, F.S. and Dean, L.A. 1954. Estimation of available phosphorus in soil by extraction with sodium bicarbonate. USDA. Circ. 939 pp.

Panse, V.G. and Sukhatme, P.V. 1962. Statistical methods for agricultural workers. $2^{\text {nd }}$ edn. New Delhi. I.C.A.R. pp-56-57.

Ramamoorthy, B.; Narasimham, R.L. and Dinesh, R.S. 1967. Fertilizer application for specific yield targets of Sonora 64 . Ind. Farming. 17(5) 43-44.

Seifritz, A.V. and Singh, J.2004. Revalidation of soil test method of potassium availability in light textured soils of arid and semi-arid regions of north India. Ann. Agri-Bio Res.9(1):99-105.

Sharma, A.R. and Mittra, B.N., 1991. Effect of different rates of application of organic and nitrogen fertilizers in a ricebased cropping system. Journal of Agricultural Science (Cambridge). 117:313-318.

Singh, V. and Singh, B., 1992. Tropical grain legume as important human foods. Economic botany, 1646: 310-321.

Snedeor, G.W. and Cochran, W.G. 1967. Statistical methods $5^{\text {th }}$ ed. Oxford and IBH. Pub. Co. Elton Press, Calcutta. $110-112$.

Subbiah, B.V. and Asija, G. L. 1956. A rapid procedure for assessment of available nitrogen in rice plots. Curr. Sci., 31:196-200.

Troug, E. 1960. Fifty years of soil testing. Transactions of $7^{\text {th }}$ international Congress of Soil Science., Commission IV, Paper No. 3(7): 46-53.

Walkley and Black, C.A. 1934. An examination of different method of determining soil organic carbon and a proved modification of chromic acid titration method. Soil Sci., 37: 29-38.

\section{How to cite this article:}

Varun Tripathi, Sobran Singh and Bal Mukund Pandey. 2019. Soil Test Crop Response studies on Cowpea (Vigna unguiculata (L). Walp.) in Mollisol of Uttarakhand, India. Int.J.Curr.Microbiol.App.Sci. 8(05): 1533-1541. doi: https://doi.org/10.20546/ijcmas.2019.805.177 